\title{
Development of Preliminary Leaf Nutrient Norms for Byadgi Chilli (Capsicum annuum L.) using DRIS Approach
}

\author{
M. Pushpalatha* and B. L. Bidari \\ Department of Soil Science and Agricultural Chemistry, College of Agriculture, \\ University of Agricultural Sciences- Dharwad- 580005, India \\ *Corresponding author
}

\begin{tabular}{l} 
K e y w o r d s \\
$\begin{array}{l}\text { DRIS, Byadgi } \\
\text { chilli, Index leaf, } \\
\text { NII, CV }\end{array}$ \\
Article Info \\
$\begin{array}{l}\text { Accepted: } \\
\text { 22 March } 2020 \\
\text { Available Online: } \\
\text { 10 April } 2020\end{array}$ \\
\hline
\end{tabular}

\section{A B S T R A C T}

\begin{abstract}
A survey was conducted during 2017-18 to study the leaf nutrient norms using Diagnosis and Recommendation Integrated System (DRIS) for Byadgi chilli crop in three district of north Karnataka. A total of 175 locations were selected and index chilli leaf samples were collected at peak flowering stage. These samples were analysed for nutrients to establish the data bank. The whole population of study area was divided into low and high yielding categories taking chilli yield of $8.50 \mathrm{q} / \mathrm{ha}$ as cut off level. Totally 28 nutrient expressions were selected as diagnostic norms that have direct relationship with chilli yield. These expressions had high variance and low co-efficient of variation (CV) that was found to have greater diagnostic precision. Few selected expressions were N/P (6.55), N/K (0.81), $\mathrm{N} / \mathrm{Ca}$ (1.91), Mg/N (0.21), N/S (5.85), Fe/N (21.57), N/Zn (0.10) etc. The nutritional imbalance index indicated an overall imbalance of the nutrients based on sum of the indices irrespective of sign. The identification of nutrients imbalance through DRIS indices indicated potassium as the most yield limiting followed by sulphur, magnesium and phosphorus. Further nutrients ranges were derived using mean and standard deviation as low, deficient, optimum, high and excess for each nutrient to serve as a diagnostic tool for yield. The optimum concentrations of $\mathrm{N}, \mathrm{P}, \mathrm{K}, \mathrm{Ca}, \mathrm{Mg}, \mathrm{S}, \mathrm{Fe}$ and $\mathrm{Zn}$ in index leaf ranged from -2.74 to $3.14,0.54-0.71,3.86-4.74,2.27-2.94,0.93-1.19,0.44-0.51$ per cent, $75.30-92.37$ and $28.28-30.15 \mathrm{mg} / \mathrm{kg}$ respectively.
\end{abstract}

\section{Introduction}

Byadgi chilli (Capsicum annuum L.) is an important spice cum vegetable crop. It belongs to the family Solanaceae, genus capsicum and the two important cultivars are Capsicum annuum L. and Capsicum frutescence L. Nutrients are essential to enhance the yield and quality of fruits. Leaf analysis provides a useful measure of the nutrient status of the plant and can help to improve the nutrients management.

The basic principle involved in leaf analysis is that, the concentration of a nutrient within the plant at any particular stage is an integrated value of all the factors that have influenced the nutrient concentration up to the time of sampling. Thus, study of relationship of the nutrient content of the plant in relation to 
plant growth is a direct approach as it addresses the plant about its nutritional problems (Chapman and Brown, 1950). Diagnosis and Recommendation Integrated System (DRIS) is a diagnostic tool which recommends nutrients application in a direct response to crop.

Most of the chilli growers in northern Karnataka are not applying the fertilizers as per the recommended doses and therefore there is imbalanced application of nutrients to meet physiological needs. Any nutrient, if not applied in required quantity and proportion may lead to either deficiency or excess. Therefore, a field survey was conducted during kharif-2017-18 to chilli growing areas of Dharwad, Gadag and Haveri districts in northern Karnataka to develop DRIS norms for Byadgi chilli crop.

\section{Materials and Methods}

A survey was conducted in three districts where Byadgi chilli crop was grown extensively in northern Karnataka. Totally 175 locations were selected based on soil type and extent of area under chilli crop in different talukas of Dharwad, Gadag and Haveri districts. At each location index leaf samples were collected (Chapman, 1964) at peak flowering stage to develop leaf nutrient norms. About 15 leaves per plant were collected from 15 to 20 plants selected randomly in each location and a total of 150 to 200 index leaves were collected to form a composite sample. The samples were taken to the laboratory for further processing and analysis. The leaf samples were analysed for nitrogen, phosphorus, potassium, sulphur calcium and magnesium as per the standard procedure outlined by (Tandon, 2009). Selected micronutrients viz., iron and zinc were also determined in di-acid extract of leaf samples analysed by using Atomic Absorption Spectrophotometer (Jaiswal,
2013). Nutrients data bank was established for the whole chilli population. The whole population of study area were divided into low and high yielding population by taking the cut off chilli yield as $8.50 \mathrm{q} / \mathrm{ha}$ as a base to establish DRIS norms.

Letzsch and Sumner (1984) indicated that, the actual cut-off value fixed for yield had little effect on developing norms as long as it was not too low. Each parameter was expressed in as many forms as $\mathrm{N} / \mathrm{P}, \mathrm{P} / \mathrm{N}, \mathrm{N}^{\prime} \mathrm{P}$, etc. and mean values for each nutrient-expression together with their associated CVs and variances, were then calculated for the two populations. The mean values of nutrientexpressions in high yielding population were chosen as diagnostic norms. Among the different forms of expressions, the one showing higher variance ratio (variance of low yielding / variance of high yielding) was selected as a norm.

DRIS provides a means of ordering nutrient ratios in the form of indices. DRIS indices were calculated as described by Walworth and Sumner (1987) using the following formula, and for nitrogen it is shown below:

$\mathrm{N}=1 / 7[-\mathrm{f}(\mathrm{P} / \mathrm{N})-\mathrm{f}(\mathrm{K} / \mathrm{N})+\mathrm{f}(\mathrm{N} / \mathrm{Ca})+\mathrm{f}(\mathrm{N} / \mathrm{Mg})-$ $\mathrm{f}(\mathrm{S} / \mathrm{N})-\mathrm{f}(\mathrm{Fe} / \mathrm{N})+\mathrm{f}(\mathrm{N} / \mathrm{Zn})]$.

$f\left(\frac{N}{P}\right)=\left\{\begin{array}{rlrl}\left(\frac{N / P}{n / p}-1\right) x \frac{1000}{C V} & \text { when } N / P & >n / p \\ 0 & \text { when } \frac{N}{P}=\frac{n}{p} \\ \left(1-\frac{n / p}{N / P}\right) x \frac{1000}{C V} & \text { when } N / P<n / p\end{array}\right.$

Where,

1. N/P: The actual value of the ratio of nitrogen and phosphorus in the leaf under diagnosis

2. $\mathrm{n} / \mathrm{p}$ : Value of the norm (which is mean value of the high-yielding population)

3. CV: Coefficient of variation of high yielding population 
Similarly, indices for other nutrients were calculated using appropriate formulae. The absolute sum (positive and negative) values of nutrient indices generate an additional index called the nutrient imbalance index (NII) (Walworth and Sumner, 1987). By using mean and standard deviation, five ranges for leaf nutrients concentrations were derived as deficient, low, optimum, high and excess for each nutrient. The optimum nutrient range is the value derived from "mean 4/3SD (standard deviation) to mean $+4 / 3$ SD". The range "low" was obtained by calculating "mean - 4/3 SD to mean - 8/3SD" and the value below "mean - 8/3 SD" was considered as deficient. The value from "mean $+4 / 3 \mathrm{SD}$ to mean $+8 / 3$ SD" was taken as high and the value above "mean $+8 / 3$ SD" was taken as exces (Bhargava and Chadha, 1993).

\section{Results and Discussion}

\section{Mean and range of index leaf nutrient concentrations}

The range and mean of nutrients concentration in index leaves of Byadgi chilli plants at peak flowering stage in the study area are presented in Table-1. The nitrogen content ranged from 2.07 to 3.50 per cent with a mean value of 2.71 per cent. Phosphorus ranged from 0.12 to 0.93 per cent with a mean value of 0.44 per cent and potassium ranged from 1.07 to 4.52 per cent with a mean of 3.22 per cent.

Similarly, calcium content in index leaf ranged from 0.72 to 3.00 per cent with a mean of 1.59 per cent while magnesium and sulphur contents ranged from 0.02 to $1.64,0.21$ to 0.69 per cent with mean values of 0.55 and 0.44 per cent respectively. For iron and zinc micronutrients, the values ranged from 37.56 to 126.84 and 21.14 to $28.82 \mathrm{mg} \mathrm{kg}^{-1}$ with mean values of 57.76 and $25.91 \mathrm{mg} \mathrm{kg}^{-1}$ respectively.

\section{DRIS ratio and norms}

A total of 28 nutrient ratios were chosen as diagnostic norms from high yielding population and are presented in Table- 2 along with their co-efficient of variation. The important nutrient ratios were $\mathrm{N} / \mathrm{K}(0.81)$, $\mathrm{N} / \mathrm{S}$ (5.85), N/Zn (0.10), Fe/N (21.57), S/K (0.14), Fe/Zn (2.21) Zn/S (56.60), Zn/K (7.87), Fe/Zn (22.18), Fe/S (123.91) etc., which showed low co-efficient of variation compared to others. The important nutrient expressions involving nitrogen were: N/P (6.55), N/K (0.81), N/Ca (1.91), N/S (5.85), $\mathrm{N} / \mathrm{Zn}$ (0.10). Similarly, important ratios involving phosphorus with other nutrients were: $\mathrm{P} / \mathrm{K}(0.14)$ and $\mathrm{P} / \mathrm{Mg}(1.08)$ and for potassium the ratios were: $\mathrm{S} / \mathrm{K}(0.14)$ and $\mathrm{Zn} / \mathrm{K}$ (7.87). Likewise, important ratios involving $\mathrm{Ca}$ and $\mathrm{Mg}$ were $\mathrm{Ca} / \mathrm{S}$ (3.40), $\mathrm{Ca} / \mathrm{Zn}$ (0.06) and $\mathrm{Mg} / \mathrm{S}$ (1.19).

Lastly for micronutrients, the expressions were $\mathrm{Fe} / \mathrm{S}$ (123.91), Zn/S (56.60) and Fe/Zn (2.21). The co-efficient of variation (CV) ranged from the lowest 13 per cent for $\mathrm{N} / \mathrm{Zn}$ to the highest 71 percent for $\mathrm{P} / \mathrm{Mg}$ indicating wide variation in their absolute concentration in the high yielding population. Maintaining the ratios of some expressions at optimum level when they were with large coefficient of variation was much less critical for the performance of the crop. Therefore, the nutrients considered as yield contributors need to be kept in a state of relative balance for maximum efficiency of dry matter production and economic yield (Anjaneyulu, 2007). Similar results were also recorded by Srijaya (2016) for chilli crop.

\section{Leaf nutrients standards}

By using mean and standard deviation for each nutrient in leaf, five ranges were derived as deficient, low, optimum, high and excess (Table 3). Optimum nitrogen content in index 
leaves of Byadgi chilli ranged from 2.74-3.14 per cent whereas optimum phosphorus content ranged from 0.54 to $0.71 \%$ indicating a lower requirement of phosphorus compared to $\mathrm{N}$.

Optimum K ranged from 3.86 to 4.74 per cent and the requirement of potassium is always next only to nitrogen as it is not only involved in the production of fruits but also in improving the quality of Byadgi chilli fruits. The optimum concentration range for calcium was 2.27-2.94 per cent and magnesium was 0.93 to 1.19 and 0.44 to 0.51 per cent for sulphur. For iron and zinc, the ranges were 75.30 to 92.37 and 28.28 to $30.15 \mathrm{mg} / \mathrm{kg}$. In most of the locations iron and zinc were sufficient in both high and low yielding locations. Ragupathi and Bhargava (1999) also developed leaf nutrient standards for mango (Cv. Alphonso) and Savitha and Anjaneyulu (2008) for sapota crop.

DRIS chart for index leaf nitrogen, phosphorus and potassium (N-P-K) nutrients combination

The mean of the nitrogen, phosphorus and potassium ratios associated with high yielding population and their standard deviation were used to construct the DRIS chart. The point of intersection of three axes viz., N/K, N/P and $\mathrm{P} / \mathrm{K}$ corresponds to the DRIS norms associated with the nutrient ratios and the values were $0.81,6.55$ and 0.14 respectively. These three values constitute the most balanced condition for nitrogen, phosphorus and sulphur nutrients and departure from this point of intersection of three nutrients to either side indicated imbalance. This can happen due to the excess of one nutrient / deficient of the other nutrient. The degree of imbalance between $\mathrm{N} \& \mathrm{P}$ or $\mathrm{N} \& \mathrm{~K}$ or $\mathrm{K} \& \mathrm{P}$ increases from the centre of the circle towards the outer.

From DRIS chart of N-P-K, the value of the of the function N/P lies beyond the outer circle in the zone of $\mathrm{P}$ insufficiency giving $\mathrm{N}$ $\mathrm{P} \downarrow \mathrm{K}$ whereas the value of $\mathrm{N} / \mathrm{K}$ also lies outside the outer circle in the zone of $\mathrm{K}$ insufficiency giving N P $\downarrow$ K $\downarrow$ and that of $\mathrm{P} / \mathrm{K}$ lies inside the inner circle in the zone of balance. Once the three common functions have been read the remining element is assigned a horizontal arrow. The final reading then becomes $\mathrm{N} \rightarrow \mathrm{P} \downarrow \mathrm{K} \downarrow$ which gives the order of requirement for $\mathrm{N}, \mathrm{P}$ and $\mathrm{K}$ in terms of limiting importance on yield as $\mathrm{K}=\mathrm{P}>\mathrm{N}$.

Table.1 Range and mean of index leaf nutrient concentrations of Byadgi chilli plants

\begin{tabular}{|l|l|l|}
\hline Nutrients (\%) & Range & Mean \\
\hline Nitrogen & $2.07-3.50$ & 2.71 \\
\hline Phosphorus & $0.12-0.93$ & 0.44 \\
\hline Potassium & $1.07-4.52$ & 3.22 \\
\hline Calcium & $0.72-3.00$ & 1.59 \\
\hline Magnesium & $0.02-1.64$ & 0.55 \\
\hline Sulphur & $0.21-0.69$ & 0.44 \\
\hline Iron $(\mathbf{m g} / \mathbf{k g})$ & $37.56-126.84$ & 57.76 \\
\hline Zinc $\mathbf{( m g / k g )}$ & $21.14-28.82$ & 25.91 \\
\hline
\end{tabular}


Table.2 DRIS norms for index leaf concentrations at peak flowering stage for high yielding locations in the study area

\begin{tabular}{|l|l|l|l|l|l|l|l|}
\hline SI. No & $\begin{array}{l}\text { Nutrient } \\
\text { Ratios }\end{array}$ & $\begin{array}{l}\text { DRIS } \\
\text { norms }\end{array}$ & $\begin{array}{l}\text { CV } \\
(\mathbf{\%})\end{array}$ & Sl. No & $\begin{array}{l}\text { Nutrient } \\
\text { Ratios }\end{array}$ & $\begin{array}{l}\text { DRIS } \\
\text { norms }\end{array}$ & $\begin{array}{l}\text { CV } \\
(\%)\end{array}$ \\
\hline $\mathbf{1}$ & $\mathrm{N} / \mathrm{P}$ & 6.55 & 39 & 15 & $\mathrm{Mg} / \mathrm{K}$ & 0.17 & 53 \\
\hline $\mathbf{2}$ & $\mathrm{N} / \mathrm{K}$ & 0.81 & 23 & 16 & $\mathrm{~S} / \mathrm{K}$ & 0.14 & 25 \\
\hline $\mathbf{3}$ & $\mathrm{N} / \mathrm{Ca}$ & 1.91 & 36 & 17 & $\mathrm{Fe} / \mathrm{K}$ & 17.26 & 30 \\
\hline $\mathbf{4}$ & $\mathrm{Mg} / \mathrm{N}$ & 0.21 & 49 & 18 & $\mathrm{Zn} / \mathrm{K}$ & 7.87 & 24 \\
\hline $\mathbf{5}$ & $\mathrm{N} / \mathrm{S}$ & 5.85 & 16 & 19 & $\mathrm{Ca} / \mathrm{Mg}$ & 3.51 & 59 \\
\hline $\mathbf{6}$ & $\mathrm{Fe} / \mathrm{N}$ & 21.57 & 24 & 20 & $\mathrm{Ca} / \mathrm{S}$ & 3.40 & 34 \\
\hline $\mathbf{7}$ & $\mathrm{N} / \mathrm{Zn}$ & 0.10 & 13 & 21 & $\mathrm{Ca} / \mathrm{Fe}$ & 0.03 & 36 \\
\hline $\mathbf{8}$ & $\mathrm{P} / \mathrm{K}$ & 0.14 & 42 & 22 & $\mathrm{Ca} / \mathrm{Zn}$ & 0.06 & 31 \\
\hline $\mathbf{9}$ & $\mathrm{Ca} / \mathrm{P}$ & 3.78 & 45 & 23 & $\mathrm{Mg} / \mathrm{S}$ & 1.19 & 47 \\
\hline $\mathbf{1 0}$ & $\mathrm{P} / \mathrm{Mg}$ & 1.08 & 71 & 24 & $\mathrm{Fe} / \mathrm{Mg}$ & 126.71 & 49 \\
\hline $\mathbf{1 1}$ & $\mathrm{S} / \mathrm{P}$ & 1.13 & 36 & 25 & $\mathrm{Zn} / \mathrm{Mg}$ & 58.95 & 50 \\
\hline $\mathbf{1 2}$ & $\mathrm{Fe} / \mathrm{P}$ & 137.38 & 36 & 26 & $\mathrm{Fe} / \mathrm{S}$ & 123.91 & 22 \\
\hline $\mathbf{1 3}$ & $\mathrm{Zn} / \mathrm{P}$ & 63.26 & 35 & 27 & $\mathrm{Zn} / \mathrm{S}$ & 56.60 & 14 \\
\hline $\mathbf{1 4}$ & $\mathrm{Ca} / \mathrm{K}$ & 0.48 & 41 & 28 & $\mathrm{Fe} / \mathrm{Zn}$ & 2.21 & 22 \\
\hline & & & & & & & \\
\hline
\end{tabular}

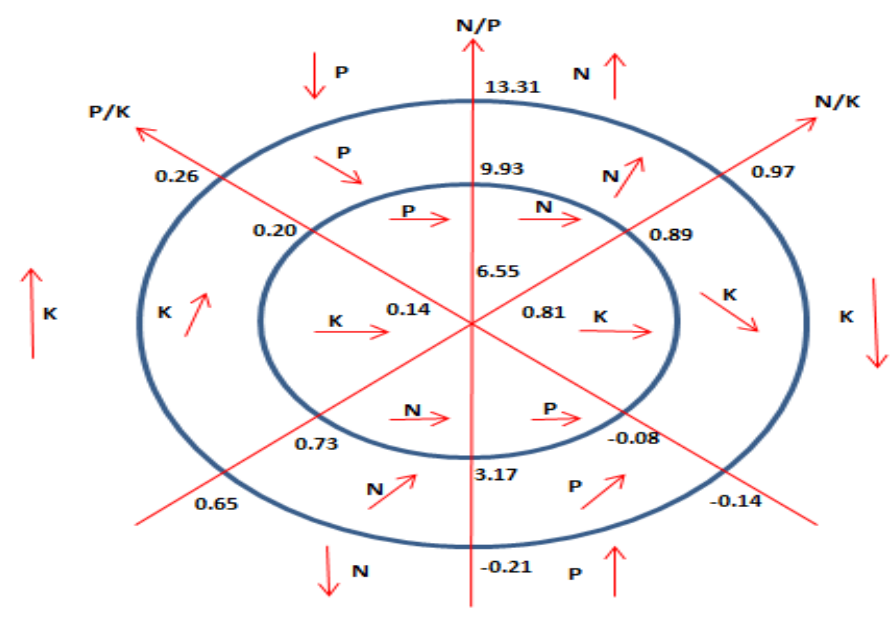

Fig.1 DRIS chart for nitrogen, phosphorus and potassium in index leaf of Byadgi chilli at peak flowering stage

\begin{tabular}{|c|c|c|c|}
\hline DRIS ratios & DRIS norms & S.D & $\mathbf{4 / 3 ~ S D ~}$ \\
\hline N/P & 6.55 & 2.53 & 3.38 \\
\hline N/K & 0.81 & 0.18 & 0.25 \\
\hline P/K & 0.14 & 0.06 & 0.08 \\
\hline
\end{tabular}


Table.3 Leaf nutrient standards established for Byadgi chilli [Cv. Dyvanur] in the high yielding locations

\begin{tabular}{|l|l|l|l|l|l|}
\hline \multirow{2}{*}{ Nutrients (\%) } & \multicolumn{5}{|c|}{ Category } \\
\cline { 2 - 7 } & Deficient & Low & Optimum & High & Excess \\
\hline Nitrogen & $<1.92$ & $1.93-2.73$ & $2.74-3.14$ & $3.15-3.54$ & $>3.55$ \\
\hline Phosphorus & $<0.02$ & $0.03-0.36$ & $0.37-0.53$ & $0.54-0.71$ & $>0.72$ \\
\hline Potassium & $<1.17$ & $1.18-2.96$ & $2.97-3.85$ & $3.86-4.74$ & $>4.75$ \\
\hline Calcium & $<0.24$ & $0.25-1.59$ & $1.60-2.26$ & $2.27-2.94$ & $>2.95$ \\
\hline Magnesium & $<0.13$ & $0.14-0.66$ & $0.67-0.92$ & $0.93-1.19$ & $>1.20$ \\
\hline Sulphur & $<0.20$ & $0.21-0.35$ & $0.36-0.43$ & $0.44-0.51$ & $>0.52$ \\
\hline Iron $(\mathbf{m g} / \mathbf{g})$ & $<24.06$ & $24.07-58.22$ & $58.23-75.29$ & $75.30-92.37$ & $>92.38$ \\
\hline Zinc $(\mathbf{m g} / \mathbf{g})$ & $<22.64$ & $22.65-26.40$ & $26.41-28.27$ & $28.28-30.15$ & $>30.16$ \\
\hline
\end{tabular}

The present investigation clearly demonstrated that DRIS approach is holistic for identify optimum nutrient concentrations in index leaf of Byagdi chilli crop and thereby emphasizing DRIS as an important and ideal technique for evolving nutrient management strategies to realize higher fruit yields.

\section{Acknowledgement}

Authors are thankful to the Department of Science and Technology, Government of India, New Delhi for awarding INSPIRE fellowship to pursue doctoral degree and execute the research work.

\section{References}

Anjaneyulu, K., 2007, Diagnostic petiole nutrient norms and identification of yield limiting nutrients in papaya (Carica papaya) using diagnosis and recommendation integrated system. Indian J. Agric. Sci., 77 (11): 711-714.

Bhargava, B. S. and Chadha, K. L., 1993, Leaf nutrient guide for fruit crops. Adv. Hort., 2: 973-1030.

Chapman, H. D., 1964, Suggested foliar sampling and handling techniques for determining the nutrient status of some field, horticultural and plantation crops. Indian J. Hort., 21
(2): 97-119.

Chapman, H. D. and Brown, S.M., 1950, Analysis of orange leaves for diagnosing nutrient status with reference to K. Hilgardia 19: 501-540.

Letzsch, W.S. and Sumner, M. E., 1984, Effect of population size and yield level in selection of diagnosis and recommendation integrated system (DRIS) norms. Comm. Soil Sci. Pl. Analysis, 15: 997-1006.

Ragupathi, H. B. and Bhargava, B. S., 1999, Preliminary nutrient norms for 'Alphonso' mango using DRIS. Indian J. Agric. Sci., 69 (9): 648-650.

Savita, B. and Anjaneyulu, K., 2008, Development of leaf nutrient norms and identification of yield-limiting nutrients using DRIS in sapota $c v$. Kalipatti. J. Hortl. Sci. 3 (2): 136-140.

Srijaya 2016, Diagnosis of yield limiting nutrients in chilli (Capsicum annuum L.,) through DRIS in Warangal district of Telangana state. Ph. D. Thesis, Acharya N G Ranga Agricultural University, Hyderabad, (India).

Tandon, H. L. S. 2009. Methods of Analysis of Soils, Plants, Water and Fertilizers (ed.,). Fertilizer development and consultation Organisation, New Delhi. pp:112.

Walworth, J. L. and Sumner, M. E., 1987, Diagnosis and Recommendation Integrated System. Adv. Soil Sci., 6: 149-188. 


\section{How to cite this article:}

Pushpalatha, M and Bidari, B. L. 2020. Development of Preliminary Leaf Nutrient Norms for Byadgi Chilli (Capsicum annuum L.) using DRIS Approach. Int.J.Curr.Microbiol.App.Sci. 9(04): 3026-3032. doi: https://doi.org/10.20546/ijcmas.2020.904.353 